\title{
Clinical Course of Pregnant Women with Maternal Hydronephrosis: Retrospective Clinical Study
}

\author{
Maternal Hidronefrozlu Gebe Kadınların Klinik Seyri: Retrospektif Klinik Çalışma
}

\author{
Barış SAYLAM ${ }^{1}$ \\ (D) 0000-0003-3256-8752 \\ Aysun SAVAŞ EFESOY ${ }^{2}$ \\ (D) 0000-0001-7801-0872 \\ Erim ERDEM ${ }^{3}$ \\ (D) 0000-0003-1754-4365
}

\begin{abstract}
Aim: The study aims to investigate the clinical course of symptomatic physiological hydronephrosis in pregnant women and the results of treatment in patients required treatment. Material and Methods: A hundred and two consecutive pregnant women who presented with clinical signs and symptoms related to the upper urinary system were included in the study. Renal ultrasonography, urinalysis, serum creatinine levels, white blood cell count, and urine culture were done in all patients at the first visit and repeated at least once a month until 1 month after delivery. In patients with acute pyelonephritis, urinalysis was repeated every 3 days until white blood cell count, erythrocyte sedimentation rate and C-reactive protein levels normalized; urine culture and kidney ultrasonography were performed monthly until 1 month after delivery. Conservative measures (positioning, analgesia, antibiotics) were used in all patients with symptomatic physiological hydronephrosis. If the patient's condition was resistant to medical treatment and the degree of hydronephrosis was increased, drainage was performed by inserting a double $\mathrm{J}$ stent into the ureter.

Results: Conservative treatments were successful in 98 (96.1\%) of 102 patients, but 4 (3.9\%) had signs and symptoms of acute pyelonephritis progressing to urosepsis. Antibiotics were continued in patients who developed pyelonephritis, symptoms regressed rapidly, signs of kidney infection returned to normal. Follow-up pregnancies ended with normal vaginal delivery.

Conclusion: Symptomatic hydronephrosis in pregnancy can be treated conservatively, should be treated carefully and patients should be followed up. However, ureteral double-J stenting is an effective and safe treatment method in patients with resistant symptoms.

Keywords: Hydronephrosis; pregnancy; renal ultrasonography.
\end{abstract}

ÖZ

Amaç: Bu çalışmanın amacı gebe kadınlarda semptomatik fizyolojik hidronefrozun klinik seyrinin ve tedavi gereken hastalarda tedavi sonuçlarının araştırılmasıdır.

Gereç ve Yöntemler: Üst üriner sistem ile ilgili klinik belirti ve semptomlarla başvuran ardışık 102 gebe kadın çalışmaya dahil edilmiştir. Tüm hastalarda ilk vizitte renal ultrasonografi, idrar tahlili, serum kreatinin düzeyi, beyaz kan hücresi sayımı ve idrar kültürü yapıldı, doğumdan 1 ay sonrasına kadar ayda en az bir kez tekrarlandı. Akut piyelonefritli hastalarda idrar tahlili, beyaz kan hücresi sayısı, eritrosit sedimantasyon hızı ve C-reaktif protein seviyeleri normalleşene kadar her 3 günde bir tekrarlandı; idrar kültürü ve böbrek ultrasonografisi doğumdan 1 ay sonrasına kadar ayda bir kez yapıldı. Semptomatik fizyolojik hidronefrozlu tüm hastalarda konservatif önlemler (pozisyon verme, analjezi, antibiyotikler) uyguland. Hastanın durumu tıbbi tedaviye dirençli ve hidronefroz derecesinde artış var ise, üretere double J stent takılarak drenaj yapıldı.

Bulgular: Konservatif tedaviler 102 hastanın 98 'inde $(\% 96,1)$ başarılıydı, ancak 4'ünde $(\% 3,9)$ ürosepsiye ilerleyen akut piyelonefrit belirtileri ve semptomları vard1. Pyelonefrit gelişen hastalarda antibiyotiklere devam edildi ve semptomları hızlı bir şekilde geriledi, böbrek enfeksiyonunun bulguları normale döndü. Takip edilen gebelikler normal vajinal doğum ile sonlandi.

Sorumlu Yazar

Barış SAYLAM

drsaylam@gmail.com

Received / Geliş Tarihi : 15.04.2021 Accepted / Kabul Tarihi : 09.07.2021 Available Online /

Çevrimiçi Yayın Tarihi : 16.07.2021
Sonuç: Gebelikte semptomatik hidronefroz konservatif olarak tedavi edilebilir, dikkatli bir şekilde tedavi edilmeli ve hastalar takip edilmelidir. Bununla birlikte dirençli semptomları olan hastalarda ureteral double-J stent takılması etkili ve güvenli bir tedavi yöntemdir.

Anahtar kelimeler: Hidronefroz; gebelik; renal ultrasonografi. 


\section{INTRODUCTION}

During pregnancy, dilatation of ureters and pelvicalyceal systems due to hormonal and mechanical reasons are commonly seen. Maternal hydronephrosis is a condition seen at rates of up to $90 \%$ in pregnancy. However, acute symptomatic dilatation of the collecting system is seen in $0.2-3 \%$ of these pregnancies $(1,2)$. Increased urine volume, growing uterus pressure, and progesterone's myorelaxant effect on smooth muscle are the main reasons for maternal hydronephrosis during pregnancy. Maternal hydronephrosis mostly affects the right side and is seen during the second half of pregnancy and also mostly is seen in primipara patients $(1,3)$. Gravid uterus and dilated ovarian veins, as well as hormonal factors, maybe the underlying mechanism of ureteral compression in the pregnant woman. As a result of this, enlargement of the urinary tract is often expected in pregnant women with a large uterus, such as twin pregnancies or cases of polyhydramnios (4). Most cases are asymptomatic even if some complaint of acute severe pain. In these patients, recurrent urinary tract infections and renal function deterioration may also occur. Most patients are a medical response to treatment, about $6 \%$ of the patients may be required urinary drainage such as ureteral catheterization procedures (5). It is still a controversial issue how to treat symptomatic hydronephrosis in pregnancy (6). In this study, it was aimed to evaluate retrospectively the clinical course of pregnant women with maternal hydronephrosis who were followed in our clinic.

\section{MATERIAL AND METHODS}

This retrospective study was carried out at Mersin City Training and Research Hospital. This study was approved by the Mersin University Clinical Research Ethics Committee (17.03.2021/239). 120 pregnant women with maternal hydronephrosis aged between 21 and 48 who consult our clinic between July 2017 and February 2020 were included. History of recurrent bladder infection was not considered exclusion criteria, while newly diagnosed kidney or ureteral stones and a history of kidney disease were considered exclusion criteria. For each woman, renal ultrasonography (Siemens Sonoline Adara, Erlangen, Germany) with a $3.5-\mathrm{MHz}$ probe was performed. Renal ultrasonography was performed at least once until 1 month after delivery. 18 of our patients had urinary calculi, 17 were in the third trimester, and one in the second trimester. They were all excluded owing to kidney stones. In all patients with symptomatic hydronephrosis and acute pyelonephritis symptoms, erythrocyte sedimentation rate (ESR), C-reactive protein (CRP), white blood cell (WBC) count and urinalysis were tested every 3 days until their normal. Also, urine culture as well as renal ultrasonography was performed monthly until 1 month after delivery. Hydronephrosis was graded according to the maximum calyceal diameter as Zwergel et al. (7). 5-10, 10-15, and >15 mm were determined mild, moderate, and severe hydronephrosis, respectively. Urinalysis, urine culture, serum creatinine levels, WBC counts were checked. All patients were treated conservatively with analgesics and intravenous fluids, and if there were signs of infection such as fever and leukocytosis, intravenous cefuroxime and gentamicin were added to the treatment. Surgical drainage was performed in cases where conservative treatment was failed, such as signs of infection that did not improve after 48 hours, impaired renal function (i.e. increase in serum creatinine or blood urea nitrogen (BUN) values), absence of 'jet mark' on renal ultrasonography that indicating ureteral flow showing ureter obstruction, or presence of persistent pain. A 4,8 F $26 \mathrm{~cm}$ double-J stent (polyurethane ureteric stent; Arılar, Istanbul, Turkey) was passed under cystoscopy with the help of intravenous sedation. With this procedure, internal drainage was provided from the ureteropelvic junction to the bladder.

\section{Statistical Analysis}

SPSS v.21.0 package program was used for statistical evaluation and $\mathrm{p}<0.05$ was considered to be statistically significant. Descriptive statistics for continuous variables were done, and also given as mean \pm standard deviation, while number and percentage values were calculated for categorical variables.

\section{RESULTS}

All patients were in the second half of pregnancy and the mean gestational week was $19 \pm 3$ (13-24). Sixty five $(63.7 \%)$ women were in their first pregnancy and 37 $(36.3 \%)$ were in their second. Ninety five $(93.1 \%)$, of them have pain in one kidney and 7 (6.9\%) in both kidneys while all unilateral ones were in the right kidney. Bacteriuria was found in $38(37.3 \%)$, pyuria in $70(68.6 \%)$ patients, while an acute urinary infection was detected in 20 (19.6\%) patients in the first visit. Bacteria were seen in the urine culture, including Escherichia coli (\%70.2), Klebsiella pneumonia (\%13.4), Enterococcus faecalis (\%10.4), mixed cultures (\%3.4) and Streptococcus agalctiae (\%2.6) detected. Patients' demographic and clinical data were shown in Table 1. At the same time, it was shown with renal ultrasonography that $60(58.8 \%)$ of the 102 patients were grade I, while 34 (33.3\%) of them were grade II, and $8(7.8 \%)$ were grade III upper urinary tract dilatation (Table 1 and 2).

Conservative treatments provided pain relief in $90(88.2 \%)$ of the patients at the end of the $5^{\text {th }}$ day. After 1 month, bacteriuria was observed in $31(30.4 \%)$ and pyuria in 22 $(21.6 \%)$ of the patients' urine. In $19(18.6 \%)$ of the patients, only recurrent flank pain was observed without any complications until delivery. In these patients, no increase in the degree of hydronephrosis was observed in renal ultrasonography until birth, and those with bacteriuria were followed up with low-dose prophylactic antimicrobial therapy. Four (3.9\%) of the patients did not respond to conservative treatment, degrees of hydronephrosis increased on ultrasonography (Table 2) and showed signs and symptoms of acute pyelonephritis (fever, high WBC count, flank pain, high CRP). Calyceal kidney diameter was above $15 \mathrm{~mm}$. ESR, CRP, WBC count and serum BUN (mmol/L) levels were higher than the conservative treatment group (Table 1). Although the treatments were arranged according to the urine culture results, patients did not respond to the treatment and urosepsis developed.

Later, a ureteral double-J stent was placed in these patients under local anesthesia. During the endoscopic procedure, urine drainage was observed after the double-J stent was placed. Four days after ureteral stenting, WBC count and 
body temperature were normal, and in all patients, the pain was resolved. Six days later, in all 4 patients the urine was also sterile. Symptoms developed in patients after double$\mathrm{J}$ stent insertion are shown in Table 3 . The pregnancies of the patients progressed smoothly and 4 patients delivered vaginally at an average of 39 weeks. One month after delivery the ureteric stent was removed without any complication. At the same time renal ultrasonography was normal in all patients and renal function remained within the normal limits as measured by serum creatinine.

Table 1. Patients' demographic and clinical data

\begin{tabular}{|c|c|c|c|c|c|}
\hline \multirow{2}{*}{ Parameter } & \multirow{2}{*}{ Conservative Treatment } & \multicolumn{4}{|c|}{ Double-J stent insertion cases } \\
\hline & & Case 1 & Case 2 & Case 3 & Case 4 \\
\hline Age (years) & $26 \pm 4$ & 29 & 20 & 30 & 30 \\
\hline GA (weeks) & $19 \pm 3$ & 28 & 26 & 28 & 26 \\
\hline GA at delivery weeks & $39.2 \pm 1.4$ & 39 & 39 & 38 & 34 \\
\hline Primipara & $65(63.7 \%)$ & Primipara & Primipara & Primipara & Primipara \\
\hline $\begin{array}{l}\text { Hydronephrosis site } \\
\text { Right } \\
\text { Left }\end{array}$ & $\begin{array}{l}89(87.3 \%) \\
13(12.7 \%)\end{array}$ & Right & Right & Right & Right \\
\hline $\begin{array}{c}\text { Hydronephrosis grade } \\
1 \\
2 \\
3\end{array}$ & $\begin{array}{c}60(58.8 \%) \\
34(33.3 \%) \\
8(7.8 \%)\end{array}$ & 3 & 2 & 3 & 3 \\
\hline Serum BUN (mmol/L) & $2.1 \pm 0.8^{\beta}$ & 9.3 & 2.5 & 10.7 & 3.6 \\
\hline Serum creatinine (mmol/dL) & $0.6 \pm 0.1^{\beta}$ & 1.2 & 0.7 & 1.3 & 0.8 \\
\hline $\mathrm{WBC}\left(\times 10^{3} / \mu \mathrm{L}\right)$ & $12.1 \pm 0.4$ & 22 & 9 & 8.5 & 11.7 \\
\hline CRP level (mg/l) & $4.2 \pm 2.2^{\beta}$ & 23.2 & 14.1 & 11.9 & 16.2 \\
\hline $\operatorname{ESR}(\mathbf{m m} / \mathbf{h r})$ & $21.3 \pm 9.4^{\beta}$ & 60 & 42 & 51 & 44 \\
\hline Hospitalization (days) & $5.3 \pm 1.6$ & 8 & 10 & 16 & 11 \\
\hline
\end{tabular}

GA: gestational age, BUN: blood urea nitrogen, WBC: white blood cell count, CRP: C-reactive protein, ESR: erythrocyte sedimentation rate, ${ }^{\beta}$ : at admission

Table 2. Renal ultrasonography in 102 pregnant women with symptomatic physiologic hydronephrosis

\begin{tabular}{lccccc}
\hline \multirow{2}{*}{ Grade } & $\begin{array}{c}\text { Calyceal Kidney } \\
\text { Diameter }\end{array}$ & \multicolumn{2}{c}{ At the first visit } & \multicolumn{2}{c}{ After therapy } \\
\cline { 2 - 6 } & Right & Left & Right & Left \\
\hline I & $\mathbf{5 - 1 0 ~} \mathbf{~ m m}$ & 52 & 8 & 22 & 2 \\
II & $\mathbf{1 0 - 1 5} \mathbf{~ m m}$ & 28 & 6 & 10 & 2 \\
III & $>\mathbf{1 5} \mathbf{~ m m}$ & 7 & 1 & 4 & 0 \\
\hline
\end{tabular}

Table 3. Symptoms noticed in four pregnant women with urosepsis caused by symptomatic physiologic hydronephrosis during for a maximum of 6 days following ureteral stenting

\begin{tabular}{lc}
\hline Symptom & $\mathbf{n}^{*}$ \\
\hline Frequency $<3 \mathrm{~h}$ & 4 \\
Stranguria & 3 \\
Hematuria & 1 \\
Loin pain & 1 \\
\hline *: Four patients had more than one symptom &
\end{tabular}

\section{DISCUSSION}

Physiological hydronephrosis in pregnant women may become symptomatic. Hydronephrosis that develops during pregnancy may be responsible for the progression of asymptomatic bacteriuria to symptomatic infection. The infection can progress if left untreated and may threaten the life of either the mother or the baby (8). It has been reported that hydronephrosis can give signs in the form of acute pain, as well as cause treatment-resistant urosepsis and renal failure (4). As previously reported, our study showed that urinary tract dilatation was much more common in primigravida (7). Ultrasonography with the assistance of a doppler is suitable for the evaluation of hydronephrosis grade and ureteric function. Intravenous pyelography was unnecessary in all cases. In most patients (96\%), symptoms declined significantly with 3 to 5 days of medical treatment (hydration, antibiotics and analgesia), this agrees with the incidence reported in previous studies. Although Zwergel et al. (7) offered $\beta 1$-adrenoreceptor blockers for acute hydronephrosis in pregnancy, we did not try on using them because of concern for the safety of the pregnant woman and her fetus. According to the literature, approximately $70-80 \%$ of pregnant women with symptomatic hydronephrosis can be treated with a conservative approach $(7,8)$. In our study, we can attribute this rate to a high value of $96.1 \%$, close follow-up, regular antibiotic use and patient compliance.

In patients with symptoms and signs of urosepsis, a ureteral double-J stent was placed immediately. Although this procedure has the risk of many complications such as vesicoureteral reflux, catheter migration, development of pyelonephritis and stone formation, no such complication was seen in our cases $(9,10)$. Patients with a double-J stent had only complaints of discomfort and pain in the suprapubic region. Notably, none of the patients needed previously practiced more aggressive modalities, such as percutaneous nephrostomy $(11,12)$. There is limited 
information on the risk of premature birth in those with renal colic without urolithiasis. Ercil et al. (1) reported that preterm labor was observed in 10 of 211 patients $(4.7 \%)$ with symptomatic physiological hydronephrosis. Additionally, the preterm birth rate was statistically higher in the surgical treatment group.

Although symptomatic hydronephrosis is seen very rarely in pregnant women, extreme care should be taken in these patients. Conservative measures should be taken for all patients with flank pain, bacteriuria or acute urinary infection in pregnant women. Urinary ultrasonography should be performed on these patients and they should be followed up.

\section{CONCLUSION}

Most patients with acute symptomatic hydronephrosis during pregnancy respond well to conservative treatment. Although our study included a small number of patients, its results are similar to the literature. Pregnancy hydronephrosis should be cared for and these patients should be followed closely.

Ethics Committee Approval: The study was approved by the Clinical Research Ethics Committee of the Mersin University (17.03.2021, 239).

Conflict of Interest: None declared by the authors.

Financial Disclosure: None declared by the authors.

Acknowledgements: None declared by the authors.

Author Contributions: Idea/Concept: BS, EE; Design: BS, ASE; Data Collection/Processing: BS, ASE; Analysis/Interpretation: BS, EE; Literature Review: BS, ASE; Drafting/Writing: BS; Critical Review: BS, EE.

\section{REFERENCES}

1. Ercil H, Arslan B, Ortoglu F, Alma E, Unal U, Deniz $\mathrm{M}$, et al. Conservative/surgical treatment predictors of maternal hydronephrosis: results of a single-center retrospective non-randomized non-controlled observational study. Int Urol Nephrol. 2017;49(8):1347-52.
2. Coban S, Biyik I, Ustunyurt E, Keles I, Guzelsoy M, Demirci $H$. Is there a relationship between the grade of maternal hydronephrosis and birth weight of the babies? J Matern Fetal Neonatal Med. 2015;28(9):1053-6.

3. Watson WJ, Brost BC. Maternal hydronephrosis in pregnancy: poor association with symptoms of flank pain. Am J Perinatol. 2006;23(8):463-6.

4. Farr A, Ott J, Kueronya V, Margreiter M, Javadli E, Einig S, et al. The association between maternal hydronephrosis and acute flank pain during pregnancy: a prospective pilot-study. J Matern Fetal Neonatal Med. 2017;30(20):2417-21.

5. Choi CI, Yu YD, Park DS. Ureteral stent insertion in the management of renal colic during pregnancy. Chonnam Med J. 2016;52(2):123-7.

6. Tsai YL, Seow KM, Yieh CH, Chong KM, Hwang JL, Lin YH, et al. Comparative study of conservative and surgical management for symptomatic moderate and severe hydronephrosis in pregnancy: a prospective randomized study. Acta Obstet Gynecol Scand. 2007;86(9):1047-50.

7. Zwergel T, Lindenmeir T, Wullich B. Management of acute hydronephrosis in pregnancy by ureteral stenting. Eur Urol. 1996;29(3):292-7.

8. Puskar D, Balagović I, Filipović A, Knezović N, Kopjar M, Huis M, et al. Symptomatic physiologic hydronephrosis in pregnancy: incidence, complications and treatment. Eur Urol. 2001;39(3):260-3.

9. Delakas D, Karyotis I, Loumbakis P, Daskalopoulos G, Kazanis J, Cranidis A. Ureteral drainage by double-Jcatheters during pregnancy. Clin Exp Obstet Gynecol. 2000;27(3-4):200-2.

10. Wymer K, Plunkett BA, Park S. Urolithiasis in pregnancy: a cost-effectiveness analysis of ureteroscopic management vs ureteral stenting. Am J Obstet Gynecol. 2015;213(5):691.e1-8.

11. Quinn AD, Kusuda L, Amar AD, Das S. Percutaneous nephrostomy for treatment of hydronephrosis of pregnancy. J Urol. 1988;139(5):1037-8.

12. vanSonnenberg E, Casola G, Talner LB, Wittich GR, Varney RR, D'Agostino HB. Symptomatic renal obstruction or urosepsis during pregnancy: treatment by sonographically guided percutaneous nephrostomy. Am J Roentgenol. 1992;158(1):91-4. 